\title{
THE RELATIONSHIP BETWEEN COORDINATION, MOTOR ABILITIES AND ANTHROPOMETRIC CHARACTERISTICS OF PRESCHOOL GIRLS
}

\author{
Dragan Marinković ${ }^{*}$ \\ Doctoral student, Faculty of Sports and Physical Education, \\ University of Novi Sad
}

\section{Abstract}

Coordination as complex motor ability in preschool age represents a base for development of other abilities and thus point out their relationships with overall motor development of a child. The goal of this research is to analyze the relationship of coordination with motor abilities and anthropometric characteristics of preschool girls. In a sample of 197 girls aged from $4-6$ years, seven tests of motor skills were applied and five anthropometric measures. Using standard multiple regression, a statistically significant correlation between motor abilities/anthropometric characteristics and coordination of preschool girls was identified. The system of motor and anthropometric variables as a whole explains $41 \%$ of variance of the depended variable. Among the variables of the predictor system, the best predictors of girls' performance on coordination test, were the following variables: hand tapping, standing broad jump and abdominal skinfold. The results suggest that the preschool girls' motor skills are related in a specific way and that coordination has a large impact on other motor skills.

Keywords: coordination, girls, preschool age, motor abilities, morphological status

\section{Introduction}

Coordination as a motor ability occupies the attention of experts and scientists. Its complexity and structure are not yet sufficiently known, so that its relationship with other components of the physical and motor development is under-researched. Relations between coordination and other dimensions in preschool children can be viewed from different perspectives. The first refers to what kind of correlation are coordination and other motor skills in. According to previous research (Lopes, Rodrigues, Maia, \& Malina, 2011; Marinkovic, 2012), a positive correlation exists; children with better coordination show greater efficiency in the performance of activities that involve other motor skills.

\footnotetext{
* Corresponding author. University of Novi Sad, Faculty of Sport and Physical Education, Lovćenska 16, 21000 Novi Sad, Serbia, e-mail: marinkovicdragan@hotmail.com

(C) 2013 Faculty of Sport and Physical Education, University of Novi Sad, Serbia
} 
Another issue refers to the relationship of coordination and anthropometric characteristics such as body weight and subcutaneous adipose tissue; the results of some research (Bala, 1981; D’Hondt et al., 2011; Drid et al., 2013; Lopes, Stodden et al., 2012) show that they correlate in a way that obese children show poor coordination and other motor skills.

Preschool age presents a very important period in the formation of motor behavior. Before entering the elementary school, a significant development of coordination skills in children occurs and it is more pronounced in boys than in girls (Broverman, Klaiber, Kobayashi, \& Vogel, 1968; Svirčević-Milovanović, 1994; Cvetković, Popović \& Jakšić, 2007; Bala et al., 2009; Sindik, 2009).

For denoting the key capabilities of human motor performance, different terms are used: motor abilities, anthropological abilities, motor dimensions, kinesiology skills, movement abilities, physical fitness, etc. Motor abilities are relatively stable congenital and acquired functional abilities of organs and organ systems of which depends the efficiency of motor activity (Ašmarin, 1990). In this paper, emphasis is placed on basic motor abilities since in the preschool age, specific motor abilities are not yet developed and they are of general type (Luria, 1976; Bala, 2002; Popović et al, 2006), that is, the abilities are not distinguished as is the case with older children, adolescents and adults. For girls of this age this specificity is also typical, because some parts of the CNS are not sufficiently developed and the preconditions for the improvement of motor skills at a higher level are not formed.

Motor development cannot be observed in isolation and it depends on many factors such as morphological characteristics, hereditary characteristics, conative characteristics and cognitive abilities, but also the environment. Many studies indicate that girls achieve poor results in most motor tests and therefore are different than boys of the same age (Bala, 2003, Montgomery et al., 2004; Telford, Salmon, Timperio, \& Crawford, 2005). Yet girls perform better on flexibility test in comparison to their male counterparts (Kosinac \& Katić, 1999; Bala, 2003; De Privitellio, Marić \& Mijan, 2006).

An integral part of motor skills is coordination, which is responsible for performing complex movements. Coordination as basic motor ability is not fully researched, although it draws the great attention of experts and scientists. The mechanism responsible for the coordination is very complex. Theoretical basis for understanding of coordination can be found in research of Kurelić and associates (1975), Viskić - Štalec \& Mejovšek (1975), Gredelj, Metikoš, Hošek, \& Momirović (1975). Generally speaking, the coordination is the basic framework for the organization of motor activities, and a good organization results in a great success in performing motor skills. That is the reason why many contemporary theories of motor skills put this motor ability in the first place, and there is a large number of similar definitions that are set by various authors and each one of them emphasizes complexity and significance of coordination (Fleishman, 1964; Momirović, 1970; Gredelj et al, 1975; Hošek, 1976; Drabik, 1996; Bompa, 1999; Stojiljković, 2003; Nićin, 2008). The sensitive period for coordination development is between 6-8 and 12 years of age (Bompa, 1999; Hahn, as cited in Knjaz, Rupčić \& Verunica 2007). The greatest development and potential in the manifestation of coordination can be expected between 19-24 years of age in boys and between 17-21 years of age in girls (Svirčević - Milovanović, 1994).

Because the coordination as a motor skill is a framework for the organization of physical activity (Viskić- Štalec \& Mejovšek, 1975), it prevails in most motor tasks. The level of coordination is an important predictor of physical activity in preschool aged children and in early school years (Lopes, Rodrigues et al., 2011). Given that the motor abilities at this age are of general character (Sabo, 2003), the coordination within the system of motor abilities is dominant and strongly affects the performance of different motor activities. Children with better coordination more efficiently perform motor activities than children whose coordination is at the lower level. Bala (1981) states that the coordination as a motor ability in girls develops more intensive after sixth year of age. 
After sixth year the curve of the ability advancement grows and it is similar to the curve that boys have in the same age. According to Popović et al. (2006) the development coordination of preschool girls has a stepwise character, but in time it develops in linear and intensive manner. In preschool girls, almost all emerging motor abilities are related to each other, and it's often spoken about the general motor factor (Bala, 1981), or a two-dimensional model where the first factor presents a general motor factor, while the second one appears as a single factor of flexibility (Bala et al., 2009).

Growth and development of an individual can be seen through the many aspects as those of psychological, functional, and those that involve anatomical and histological changes. The building of a specific structure and function of organ systems represents a process of tissue differentiation and functional maturation which altogether represents a process of physical development (Jakonić, 2003).

Morphological characteristics represent the biological basis that generates manifestation of anthropometric characteristics, such as body height and weight, the volume of the body and extremities, length and thickness of the long bones (parts of the legs and the corresponding joints), skin folds, etc. They define the growth and development of children, as well as their physical structure (constitution), by determining the structure of morphological characteristics (Bala, 2007). Anthropometric measures are the ones that can be measured with anthropometric instruments on the human body. They can be of manifest and latent character (Bala, 1981). Most of the body measurements, with the exception of subcutaneous adipose tissue and measures of the head and face, follow the general curve of growth and development. Malina and Bouchard (1991) proved by longitudinal data that the differences between boys and girls in most of the measured anthropometric characteristics (body height, body weight, sitting height, leg length, hip width, shoulder width, etc.) are almost insignificant until the 13-14 years of age.

Studies dealing with anthropometric characteristics of preschool children identified different number of latent factors (Momirović et al, 1967; Momirović, 1970; Kurelić et al., 1975; Bala, 1977; Szirovicza, Momirović, Hošek \& Gredelj, 1980; Katić, Zagorac, Živičnjak \& Hraski, 1994). The growth of the anthropometric measures of girls is continuous and shows different variability across the age groups (Bala, 1981). This variability is particularly evident in variables assessing subcutaneous tissue, with girls having significantly higher scores (Bala, 1981; Bala et al., 2009; Horvat, Mišigoj Duraković, \& Prskalo, 2009). In other anthropometric characteristics, it seems that there is no difference between boys and girls at this age (Katić et al, 1994; Krističević, Delija, and Horvat, 1999).

Relationship of anthropometric characteristics and coordination in preschool girls is not well known. However, previous findings suggest that body height significantly affects the performance on coordination tests. The smallest effect of anthropometric characteristics is found in tasks that depend on the mechanism of central movement control. Subcutaneous adipose tissue generally has a negative correlation with all motor abilities, including coordination. In the same time, the obesity is increasing globally (Ogden et al., 2006; Wang \& Lobstein, 2006) and its influence on effectiveness in coordination tasks is being considered (Tokmakidis, Kasambalis \& Christodoulos, 2006). Most of the findings indicate a negative relationship of weight and greater amounts of subcutaneous adipose tissue with coordination (Bala, 1981; Graf, Koch, et al, 2004; Wong \& Cheng, 2006; Graf, Jouck, et al, 2007; Bala et al, 2009; Popović \& Radanović, 2010; D’ Hondt et al, 2011; Lopes, Stodden et al., 2011). According to these studies, girls who have greater amounts of subcutaneous adipose tissue and also a higher body mass index, have poor coordination.

The aim of this study was to analyze a relationship of coordination with the anthropometric characteristics and motor abilities of preschool girls. 


\section{METHOD}

The survey applied a sample of 197 girls, aged 4-6, enrolled in kindergartens in Novi Sad, capital city of the northern province of Serbia.

Measuring instruments used in this study assess two domains - anthropometric and motor. Anthropometric measures were applied according to the International Biological Program (IBP) (Lohman, Roche \& Martorell, 1988). The sample of anthropometric measures, selected according to the previously mentioned model of morphological traits (Bala, 1981), included:

Skeleton dimension:

1. Body height (mm) - aheight

Body volume and subcutaneous fat:

2. Body weight $(0.1 \mathrm{~kg})$ - aweight

3. Abdominal skinfold $(0.1 \mathrm{~mm})$ - anbelly

4. Subscapular skinfold $(0.1 \mathrm{~mm})$ - anback

5. Triceps skinfold $(0.1 \mathrm{~mm})$ - anupperarm

Motor testing, realized according to standardized procedure for this population (Bala, Stojanović M. V., \& Stojanović, M., 2007). The following test battery was applied:

Body coordination and reorganization of movement stereotype:

1. Obstacle course backwards $(0.1 \mathrm{~s})$ - mpolygon;

2. Standing broad jump $(\mathrm{cm})$ - mlongj;

3. 20-m dash (0.1s) - mt20.

Static strength:

4. Pull-up endurance test $(0.1 \mathrm{~s})$ - mendurance

Movement frequency:

5. Arm plate tapping (freq.) - mtapping

Flexibility:

6. Sit and reach test $(\mathrm{cm})-$ mpbend

Repetitive abdominal strength:

7. Crossed-arm sit-ups (freq.) - mplift

The obtained data were analyzed by standard multiple regression to determine the linear model of the criterion variable, which in this case was coordination (Obstacle course backwards) and the system of predictor variables, comprising motor variables $(\mathrm{N}=7)$ and anthropometric measures $(\mathrm{N}=5)$. The analysis was carried out by SPSS 20.0 statistical package. 


\section{Results}

This study was aiming to investigate the relationship of coordination with motor abilities and anthropometric dimensions in preschool girls. The results obtained by statistical analysis are presented in following tables and figures.

Table 1

Descriptive statistic of analyzed variables

\begin{tabular}{lrrrrr}
\hline Variable & $A M$ & $S D$ & KV\% & Min & Max \\
\hline mt20 & 56.38 & 8.00 & 14.19 & 41 & 87 \\
mpolygon & 365.19 & 156.57 & 42.88 & 106 & 1143 \\
mtapping & 14.89 & 3.43 & 23.04 & 5 & 24 \\
mpbend & 40.11 & 6.69 & 16.68 & 27 & 59 \\
mslongj & 99.17 & 21.13 & 21.31 & 40 & 150 \\
mendurance & 110.84 & 102.71 & 92.66 & 0 & 571 \\
mplift & 20.88 & 9.49 & 45.50 & 0 & 47 \\
aheight & 1164.22 & 79.41 & 6.82 & 976 & 1413 \\
aweight & 215.67 & 45.40 & 21.06 & 136 & 486 \\
anbelly & 78.92 & 45.98 & 58.27 & 28 & 300 \\
anback & 71.31 & 30.04 & 42.13 & 36 & 246 \\
anupperarm & 97.36 & 31.46 & 32.31 & 46 & 228 \\
\hline
\end{tabular}

Legend: AM - arithmetic mean; SD - standard deviation; KV\% - coefficient of variation;

Min - minimal values; Max - maximal values; Skew- skewness; Kurt- kurtosis.

Table 1 presents descriptive data on motor abilities and anthropometric characteristics of the analyzed sample. Based on variability measures, it can be concluded that the sample is most heterogeneous when it comes to performance motor test "pull-ups", then "Crossed-arm sit-ups" and "Obstacle course backwards". The highest individual variability in terms of anthropometric variables is registered in skinfolds, and the lowest in body height.

To examine the combined impact of motor and anthropometric variables on performance in coordination test, a predictor system was formed comprising all motor and anthropometric variables included in this study. The results presented in Tables $2-3$ show the proportion of criterion total variance explained by the predictor system, as well as significance of particular predictor in explanation of total variance in coordination test. 
Table 2

Regression results

\begin{tabular}{cccc}
\hline $\mathrm{R}$ & $\begin{array}{c}\text { Coefficient of } \\
\text { determination }\end{array}$ & $\begin{array}{c}\text { Corrected coefficient } \\
\text { of determination }\end{array}$ & Standard error \\
\hline .640 & .409 & .374 & 123.918 \\
\hline
\end{tabular}

Legend: R- Coefficient of correlation

As can be seen from Table 2, the established system of predictor variables explain almost $41 \%$ of the coordination variance in the sample of preschool girls $(\mathrm{R}=.409)$.

Table 3

Value and significance of beta coefficient

\begin{tabular}{lccc}
\hline Variable system & $\begin{array}{c}\text { Standardized } \\
\text { Beta coefficient }\end{array}$ & $t$ & $p$ \\
\hline mt20 & .086 & 1.000 & .318 \\
mtapping & -.180 & -2.559 & $\mathbf{. 0 1 1}$ \\
mpretk1 & -.053 & -.817 & .415 \\
mskokda & -.232 & -2.440 & $\mathbf{. 0 1 6}$ \\
mizdrzaj & -.046 & -.679 & .498 \\
mpodiza & -.069 & -.964 & .336 \\
aheight & -.147 & -1.053 & .294 \\
aweight & .006 & .033 & .974 \\
anbelly &. $\mathbf{3 3 1}$ & 2.267 & $\mathbf{0 2 5}$ \\
anback & -.099 & -.737 & .462 \\
anupperarm & .023 & .225 & .822 \\
\hline & & $\mathrm{F}$ & $\mathrm{P}$ \\
& & 11.466 & .000 \\
\hline
\end{tabular}

Legend: $\mathrm{t}$ - $\mathrm{t}$ test values; $\mathrm{p}=$ level of significance; F-multivariate variance analysis test; $\mathrm{P}=$ level of significance.

From the values of standardized beta coefficients (Table 3) it can be seen that the largest, and also statistically significant values were obtained in hand tapping test, standing broad jump test and abdominal skin folds measures. Arm plate tapping has a negative value of beta coefficient, which means: the higher frequency of tapping, the better performance on the coordination test. As for the standing broad jump, higher scores on standing broad jump predicts better results on the coordination test.

Excessive subcutaneous adipose tissue negatively affects the performance on the coordination test, thus the greater the amount of adipose tissue, the test performance is worse. 


\section{Discussion}

The study was conducted in order to determine the relation of coordination with motor and anthropometric characteristics of the preschool girls. Standard multiple regression analysis was conducted in order to identify the direction and strength of such relationship.

A combined predictor system is formed, consisting of motor and anthropometric variables, in order to investigate its relation to the criterion variable (obstacle course backwards).

The entire system of motor and anthropometric variables explained $41 \%$ of variance of the dependent variable. The unexplained variance can probably be attributed to motor abilities and anthropometric characteristics that were not included in this research, as well as to the other characteristics like conative, cognitive and social dimensions of the preschool aged girls.

Although the predictor system as a whole is significant in prediction of the criterion variable, the coordination could be best predicted by performance in standing broad jump and arm plate tapping, and by abdominal skin fold amounts. Girls who scored higher in tests of arm plate tapping and standing broad jump, and which had less abdominal subcutaneous fat, performed better on tests of obstacle course backwards. As for the standing broad jump, the obtained result could be explained by the fact that this test is considered to be an indirect test of coordination and reorganization of movement stereotypes for preschool children. The frequency of movements refers to the aspect of speed, and since the obstacle course must be performed as fast as possible, it is understandable that faster girls perform better on the obstacle course too. It may be noted that in combined predictor model, the body height was not a significant predictor. The results suggest that the motor abilities are better predictors of coordination in preschool girls, than anthropometric characteristics. These results can be explained by the trend and level of growth and development of the morphological structure and the development of the central nervous system, and also the physical activity of girls (Bala et al., 2009). At preschool age, the general character of motor skills is notable for girls (Ismail \& Gruber, 1971; Luria, 1976; Bala, 1981; Bala, 2002; Sabo, 2003; Fratrić \& Rubin, 2006; Popović et al., 2006), and our findings are consistent with previous studies.

Possible limitations of the research refer to the characteristics and the size of the participants sample and the limited number of predictor variables employed. However, identifying the relationship between coordination and other motor dimensions, as well as anthropometric characteristics, might be useful for extending the theoretical and empirical knowledge. Developmentally appropriate physical activity for preschool children can greatly contribute to the health and overall well-being of the children, with parents and educators being main figures in supporting and enhancing children's motor development.

\section{References}

Ašmarin, V. A. (1990). Teorija i metodika fizičeskogo vospitanija. Moskva: Prosveščenie.

Bala, G. (1977). Struktura antropometrijskih dimenzija kod osoba ženskog pola. Kineziologija, $7(1-2), 13-22$.

Bala, G. (1981). Struktura i razvoj morfoloških i motoričkih dimenzija dece SAP Vojvodine. Novi Sad: Fakultet fizičke kulture. 
Bala, G. (2002). Strukturalne razlike motoričkih sposobnosti dečaka i devojčica u predškolskom uzrastu. Pedagoška stvarnost, 48(9-10), 744-752.

Bala, G. (2003). Kvantitativne razlike osnovnih antropometrijskih karakteristika i motoričkih sposobnosti dečaka i devojčica u predškolskom uzrastu. U XLII Kongres antropologa Jugoslavije: Izvodi saopštenja (p. 72).

Bala, G. (2007). Morfološke karakteristike predškolske dece. U G. Bala (Ed.), Antropološke karakteristike i sposobnosti predškolske dece (pp. 33-66). Novi Sad: Fakultet sporta i fizičkog vaspitanja.

Bala, G., Jakšić, D., \& Popović, B. (2009). Trend relacija morfoloških karakteristika i motoričkih sposobnosti dece. U Relacije antropoloških karakteristika i sposobnosti predškolske dece (pp. 61-112). Novi Sad: Fakultet sporta i fizičkog vaspitanja.

Bala, G., Stojanović, M. V., \& Stojanović, M. (2007). Merenje i definisanje motoričkih sposobnosti dece. Novi Sad: Fakultet sporta i fizičkog vaspitanja.

Bompa, T. O. (1999). Periodization. Theory and Methodology of Training. Champaign, IL: Human Kinetics.

Broverman, D. M., Klaiber, E. L., Kobayashi, Y., \& Vogel, W. (1968). Roles of activation and inhibition in sex differences in cognitive abilities. Psychological Review, 75(1), 23-50.

Cvetković, M., Obradović, J., \& Krneta, Ž. (2007). Trend razvoja motoričkih sposobnosti dece nižeg školskog uzrsta. U G. Bala (Ed.), Zbornik radova interdisciplinarne naučene konferencije sa međunarodnim učešćem "Antropološki status i fizička aktivnost dece i omladine”" (pp. 55-64). Novi Sad: Fakultet sporta i fizičkog vaspitanja.

Cvetković, M., Popović, B., \& Jakšić, D. (2007). Razlike u motoričkim sposobnostima predškolske dece u odnosu na pol. U N. Smajlović (Ed.), Zbornik naučnih i stručnih radova II međunarodnog simpozijuma "Nove tehnologije u sportu”(pp. 288-293). Sarajevo: Fakultet sporta i tjelesnog odgoja.

D’Hondt, E., Deforche, B., Vaeyens, R., Vandorpe, B., Vandendriessche, J., Pion, J., . . \& Lenoir, M. (2010). Gross motor coordination in relation to weight status and age in 5- to 12-yearold boys and girls: A cross-sectional study. International Journal of Pediatric Obesity, 6, $556-564$

De Privitellio, S., Maric, Ž., \& Mijan, J. (2006). Razlike u motoričkim sposobnostima devojčica i dečaka predškolske dobi. U G. Bala (Ed.), Zbornik radova interdisciplinarne naučene konferencije sa međunarodnim učešćem "Antropološki status i fizička aktivnost dece $i$ omladine” (pp. 57-65). Novi Sad: Fakultet sporta i fizičkog vaspitanja.

Drabik, J. (1996). Children and Sports Training. Island Point, VT: Stadion Publishing Company.

Drid, P., Vujkov, S., Jakšić, D., Trivić, T., Marinković, D., \& Bala, G. (2013). Differences in motor and cognitive abilities of children depending on their body mass index and subcutaneous adipose tissue. Collegium Antropologicum, 37(2), 171-177.

Fleishman, E. A. (1964). The Structure and Measurement of Physical Fitness. Englewood Cliffs, N. J.: Prentice-Hall.

Fratrić, F., \& Rubin, P. (2006). Kvantitativne razlike motoričkog statusa dečaka i devojčica uzrasta 4-7 godina sa teritorije Novog Sada. U: G. Bala G.(Ed.) Zbornik radova interdisciplinarne naučne konferencije sa međunarodnim učešćem Antropološki status i fizička aktivnost dece $i$ omladine (pp. 51-56). Novi Sad: Fakultet sporta i fizičkog vaspitanja. 
Graf, C., Jouck, S., Koch, B., Staudenmaier, K., Von Schlenk, D., Predel, H. G., . . \& Dordel, S. (2007). Motorische Defizite - wie schwer wiegen sie? Übergewicht und Adipositas im Kindes- und Jugendalter. Monatszeitschrift Kinderheilkunde, 155(7), 631-637.

Graf, C., Koch, B., Kretschmann-Kandel, E., Falkowski, G., Christ, H., \& Coburger, S. (2004). Correlation between BMI, leisure habits and motor abilities in childhood. International Journal of Obesity and Related Metabolic Disorders, 28(1), 22-26.

Gredelj, M., Metikoš, D., Hošek, A. \& Momirović, K. (1975). Model hijerarhijske strukture motoričkih sposobnosti. Rezultati dobijeni primjenom jednog neoklasičnog postupka za procjenu latentnih dimenzija. Kineziologija, 5, 7-81.

Horvat, V., Mišigoj-Duraković, M. \& Prskalo, I. (2009). Body size and body composition change trends in preschool children over a period of five years. Collegium Antropologicum, 33(1), 99-103.

Hošek, A. (1976). Struktura koordinacije (The structure of coordination). Kineziologija, 6(1-2), $151-192$.

Ismail, A. H., \& Gruber, J. J. (1971). Integrated Development-Motor Aptitude and Intellectual Performance. Columbus: Charles E. Merrill Books.

Jakonić, D. (2003). Osnove sportske medicine. Novi Sad: Fakultet sporta i fizičkog vaspitanja.

Katić, R., Zagorac, N., Živičnjak, M., \& Hraski, Ž. (1994). Taxonomic analysis of morphological/ motor characteristics in seven-year old girls. Collegium Antropologicum, 18(1), 141-154.

Knjaz, D., Rupčić, T., \& Verunica, Z. (2007). Razvoj koordinacije kroz senzitivna razdoblja s posebnim naglaskom na košarkaške programe. U 16. ljetna škola kineziologa Republike Hrvatske Antropološke, metodičke, metodološke i stručne pretpostavke rada u područjima edukacije, sporta, sportske rekreacije i kineziterapije zbornik radova (pp. 444-449). Zagreb: Hrvatski kineziološki savez.

Kosinac, Z., \& Katić, R. (1999). Longitudinalna studija razvoja morfološko-motoričkih karakteristika dečaka i devojčica od 5. do 7. godina. U II međunarodna znanstvena konferencija (pp. 144-147). Dubrovnik.

Krističević, T., Delija, K., \& Horvat, V. (1999). Usporedbe nekih antropometrijskih karakteristika dece predškolske dobi s obzirom na spol. Napredak, 140(3), 349-355.

Kurelić, N., Momirović, K., Stojanović, M., Šturm, J., Radojević, Đ. \& Viskić-Štalec, N. (1975). Struktura i razvoj morfoloških i motoričkih dimenzija omladine. Beograd: Institut za naučna istraživanja Fakulteta za fizičko vaspitanje.

Lohman, T. G., Roche, A. F., \& Martorell, R. (1988). Anthropometric Standardization Reference Manual. Chicago: Human Kinetics Books.

Lopes, V. P., Rodrigues, L. P., Maia, J. A. R., \& Malina, R. M. (2011). Motor coordination as predictor of physical activity in childhood. Scandinavian Journal of Medicine and Science in Sports, 21, 663-669.

Lopes, V. P., Stodden, D. F., Bianchi, M. M., Maia, J. A., \& Rodrigues, L. P. (2011). Correlation between BMI and motor coordination in children. Journal of Science and Medicine in Sport, 15(1), 38-43.

Luria, A. R. (1976). Osnovi neuropsihologije. Beograd: Nolit.

Malina, R. M., \& Bouchard, C. (1991). Growth, Maturation, and Physical Activity. Champaign, IL: Human Kinetics Books. 
Momirović, K. (1970). Komparativna analiza latentnih antropometrijskih dimenzija muškaraca i žena. Glasnik antropološkog društva Jugoslavije, 7, 193-207.

Montgomery, C., Reilly, J. J., Jackson, D. M., Kelly, L. A., Slater, C., Paton, J. Y., . . \&\& Grant, S. (2004). Relation between physical activity and energy expenditure in a representative sample of young children. American Journal of Clinical Nutrition, 80, 591-596.

Nićin, Đ. (2008). Antropomotorika: teorija. Beograd: Fakultet za menadžment i sport.

Ogden, C. L., Carroll, M. D., Curtin, L. R., McDowell, M. A., Tabak, C. J., \& Flegal, K. M. (2006). Prevalence of overweight and obesity in the United States, 1999-2004. JAMA, 295(13), $1549-1555$.

Popović, B. \& Radanović, D. (2010). Relacije morfoloških karakteristika i koordinacije kod devojčica koje se bave gimnastičkim aktivnostima. Glasnik Antropološkog društva Srbije, $45,243-252$.

Popović, B., Cvetković, M., \& Grujičić, D. (2006). Trend razvoja motoričkih sposobnosti predškolske dece. U G. Bala (Ed.), Zbornik radova interdisciplinarne naučene konferencije sa međunarodnim učešćem "Antropološki status i fizička aktivnost dece i omladine” (pp. 21-30). Novi Sad: Fakultet sporta i fizičkog vaspitanja.

Sabo, E. (2003). Struktura motoričkog prostora i razlike u motoričkim sposobnostima devojčica predškolskog uzrasta pri upisu u osnovnu školu. Norma, 9(2-3), 185-196.

Sindik, J. (2009).Kineziološki programi u dečijim vrtićima kao sredstvo očuvanja detetova zdravlja i poticanja razvoja. Medica Jadertina, 39(1-2), 19-28.

Stojiljković, S. (2003). Osnove opšte antropomotorike. Niš: Studentski kulturni centar.

Svirčević-Milovanović, K. (1994). Koordinacija sa primenom sredstava za njeno poboljšanje. Diplomski rad. Novi Sad: Fakultet fizičke kulture.

Szirovicza, L., Momirović, K., Hošek, A. \& Gredelj, M. (1980). Latentne morfološke dimenzije određene na temelju faktorskog i taksonomskog modela u standardiziranom image prostoru. Kineziologija, 3, 15-20.

Telford, A., Salmon, J., Timperio, A., \& Crawford, D. (2005). Examining physical activity among 5- to 6- and 10- to 12-year-old children: The Children's Leisure Activities study. Pediatric Exercise Science, 17, 266-280.

Tokmakidis, S. P., Kasambalis, A., \& Christodoulos, A. D. (2006). Fitness levels of Greek primary schoolchildren in relationship to overweight and obesity. European Journal of Pediatrics, 165(12), 867-874.

Viskić-Štalec, N., \& Mejovšek, M. (1975). Kanoničke relacije prostora koordinacije i prostora motorike. Kineziologija, 5, 83-112.

Wang, Y., \& Lobstein, T. (2006). Worldwide trends in childhood overweight and obesity. International Journal of Pediatric Obesity, 1, 11-25.

Wong, A. K. Y., \& Cheung, S. Y. (2006). Gross motor skills performance of Hong Kong Chinese children. Journal of Physical Education and Recreation (Hong Kong), 12(2), 23-29. 